\title{
Free Cash Flow, Financial Distress and Debt Policy Toward Earnings Management in Indonesian Banking Sector
}

\author{
Dendi Purnama ${ }^{1}$, Amir Hamzah ${ }^{2}$, Oktaviani Rita Puspasari ${ }^{3}$, Siti Nuke Nurfatimah ${ }^{4}$, \\ Enung Nurhayati ${ }^{5}$ \\ ${ }^{12345}$ Fakultas Ekonomi, Universitas Kuningan, Indonesia
}

\{dendi.purnama@uniku.ac.id ${ }^{1}$,amir.hamzah@uniku.ac.id², oktaviani.rita.puspasari@uniku.ac.id ${ }^{3}$, siti.nuke.nurfatimah@uniku.ac.id4, enung.nurhayati@uniku.ac.id5\}

\begin{abstract}
This study aims at analyzing the effect of free cash flow, financial distress and debt policy toward earnings management in Indonesian Banking Sector. The method used in this research is verification method. The sampling technique used is purposive sampling which obtained 43 banking companies of 45 banking population in Indonesia, and the total 215 of data observation. The data analysis technique used is panel data regression analysis. The results of the study are free cash flow and financial distress has positive significant effect toward earnings management, while debt policy has a negative effect toward earnings management
\end{abstract}

Keywords: Earnings management; free cash flow; financial distress; and debt policy.

\section{Introduction}

Analysis of earnings information is needed by external parties in assessing company performance. This information is presented in the financial statements which are then used by stakeholders in making decisions related to the company. This is what makes earnings information often the target of opportunistic actions by management in fulfilling their interests. Various efforts are made in managing company profits according to their goals, it is not uncommon for accounting policies to be exploited to disguise the moral hazard activities that are carried out. There are several hypotheses related to the manager's motives for taking earnings management actions or what is more commonly known as earnings management. In accordance with the positive accounting theory developed by [1], the motives for managers in conducting earnings management can be in the form of bonus plan hypotheses, debt covenant hypotheses and political cost hypotheses where all of these motives are adjusted to the goals the manager wants to achieve. Managers in this case as representatives of management have more information than external stakeholders. This condition of information asymmetry causes agency conflicts to emerge, namely from the principal as the owner of the company and management as the manager of the business.

According to [2], earnings management is an attempt by company managers to intervene or influence information in financial reports with the aim of tricking stakeholders who want to know the company's performance and condition. The fundamental reason for the emergence of earnings management is that the market price of a company's shares is significantly influenced by earnings, risk and expectations. Therefore, companies whose profits always increase steadily from time to time will result in increased corporate risk, therefore many companies 
manage their earnings as an effort to reduce risk. The practice of earnings management was even found in the banking sector in Indonesia, where there are various parties that can be involved, such as company managers or even internal and external auditors. Several cases that occurred in Indonesian banking sector are: a financial restatement report of 2015, 2016, 2017, revisions were made in the delivery of 2016 net profit, which was IDR 183.56 billion from IDR 1.08 trillion previously reported from (www.cnbcindonesia. com accessed on 11 November 2020).

The case above is an example of the practice of earnings management that occurs in banking companies in Indonesia which is carried out with a specific motive. The existence of this condition certainly has a detrimental impact on investors and reduces the integrity of the company in public. Statement of Financial Accounting Concept (SFAC) No. 2 explains that the integrity of financial statement information is a condition in which the information in the financial statements is presented fairly, unbiased and honestly. There are several factors that can influence the emergence of earnings management practices in companies, including free cash flow, financial distress, and debt policy.

[3] stated that high free cash flow will provide opportunities for managers in managing company revenue and profits, but in these conditions it can cause agency problems due to information asymmetry. High free cash flow can be utilized by company management to obtain incentives [4]. However, high free cash flow can also be used by companies in company expansion so that investors will be quite satisfied with the company's performance. However, if the company's performance is poor, the manager can act opportunistically by increasing accounting profit and managing income to hide its performance so the profits would look good in accordance with the bonus plan hypothesis, and vice versa, when the company is in good performance, management will reduce profits to avoid large taxes [5]. The results of research by [6] suggest that free cash flow has a significant positive effect on earnings management.

Financial Distress is a condition in which a company experiences a decline in its financial condition before the occurrence of bankruptcy or liquidation [7]. When a company is in financial distress, this will affect significantly on the economy [3]. [8] opine that financial distress is a condition in which a company experiencing financial difficulties in a situation where the agreement or contract with creditors is not functioning properly or in a difficult stage. Thus, the company will experience a recession which then enters the stage of a financial crisis. When companies are in a financial recession stage, this will allow management to incentivize earnings management practices [9]. The choice of accounting policy in increasing or decreasing discretionary accrual income depends on how severe the financial distress occurs [10]. The emergence of a desire to manage earnings in order to improve performance is contrary to the wishes of the principal, causing agency problem [3]. The results of [11] research show that financial distress has a significant positive effect on earnings management.

The company's debt policy is a policy taken by the management in order to obtain a source of financing (funds) from a third party to finance the company's operational activities [12]. The debt policy proxy in this study uses the Debt to Equity Ratio. Company debt policy is a policy related to the company's fund structure that funds the company in the long term consisting of debt and equity (preferred stock and common stock) [13]. The higher the leverage, the greater the company's debt, so the greater the risk faced by company management. As a result, these conditions encourage company management to perform income smoothing in line with the results of [14] in [15]. Likewise, research conducted by [16] states that high leverage encourages company management to manage earnings. The 
results of research by [17] show that debt policy represented by a debt to equity ratio has a significant positive effect on earnings management.

Based on the case above, it shows that the current practice of earnings management has spread to various business sectors including the banking industry. Therefore, researchers are interested in knowing and obtaining empirical evidence about the effect of free cash flow, financial distress and debt policies on earnings management practices. It is hoped that this will serve as a reference for the banking industry, especially at the level of supervision and risk management, to pay more attention to these three aspects to prevent deviant earnings management practices and harm the company's reputation.

\section{Method}

This research uses descriptive and verification methods with a quantitative approach. The research variables consist of free cash flow, financial distress which uses the Almants Z Score formula, and debt policy as measured by the DER ratio or debt to equity ratio, while the dependent variable consists of earnings management. The population in this study are bank sector companies listed on the Indonesia Stock Exchange. With a sample size of 43 banks for 5 years. The data analysis technique used in this study is descriptive and verification analysis with panel data regression analysis techniques.

\section{Result and Discussion}

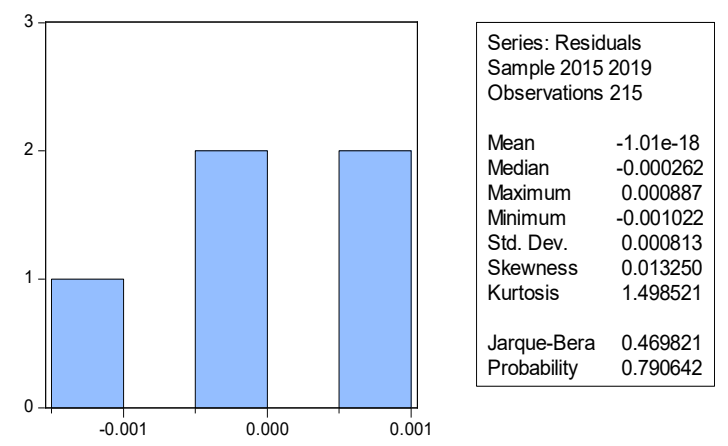

Fig 1. Normality Test Results

Based on the Figure above, it can be seen that the probability value or $\mathrm{P}$ value is $0.790642>0.05$. This means that $\mathrm{H} 0$ is accepted and $\mathrm{H} 1$ is rejected or the data used is normally distributed and in this study the normality test is fulfilled.

Table 2. The Autocorrelation Test Results

Breusch-Godfrey Serial Correlation LM Test:

\begin{tabular}{llll} 
F-statistic & 0.858673 & Prob. F(2,213) & 0.4305 \\
Obs*R-squared & 1.796754 & Prob. Chi-Square(2) & 0.8912 \\
\hline
\end{tabular}


Based on the table above, it can be seen that the P Value Obs * Square is $0.8912>0.05$, so $\mathrm{H} 0$ is accepted, meaning that the data used in this study does not have autocorrelation in the regression model.

Table 3. Heteroscedasticity test results: Breusch-Pagan-Godfrey

\begin{tabular}{llll}
\hline F-statistic & 946.2002 & Prob. F(213,2) & 0.0239 \\
\hline Obs*R-squared & 4.998239 & Prob. Chi-Square(2) & 0.1719
\end{tabular}

Based on the table above, the p-value of Obs * R-Square is $0.1719>0.05$, then $\mathrm{H}_{0}$ is accepted. This means that in this study there is no heteroscedasticity.

Table 4. Multicollinearity Test Results

\begin{tabular}{ccccc}
\hline & EM & FCF & FD & DP \\
\hline EM & 1 & 0.347212 & 0.240675 & 0.062628 \\
FCF & 0.347212 & 1 & 0.344145 & -0.332681 \\
FD & 0.240675 & 0.344145 & 1 & -0.046834 \\
DP & 0.062628 & 0.332681 & -0.046834 & 1 \\
\hline
\end{tabular}

Source: Output Eviews 9.0

Based on the table above, it can be seen that there are no independent variables whose coefficient is more than 0.8 , so it can be concluded that Multicollinearity in the correlation coefficient between variables in this study does not occur.

Table 5. Common Effect Estimation Results

\begin{tabular}{crrrr}
\hline Variable & Coefficient & Std. Error & t-Statistic & Prob. \\
\hline C & 0.607108 & 0.004595 & 1.546991 & 0.3653 \\
FCF & 0.578126 & 4.857806 & 5.982910 & 0.0000 \\
FD & 0.408915 & 0.000309 & 3.691201 & 0.0002 \\
DP & -0.330936 & 0.004751 & -2.719016 & 0.0012 \\
\hline
\end{tabular}

Source: Output Eviews 9.0

The results of data processing which uses the regression method for the model Common Effect is as follows:

$$
\mathrm{Y}_{\mathrm{EM}}=0.607108+0.578126_{\mathrm{FCF}}+0.408915_{\mathrm{FD}^{-}} 0.330936_{\mathrm{DP}}+\varepsilon
$$

Table 6. Test Model Fit

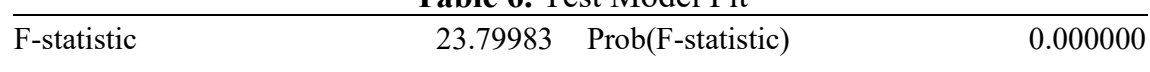

Source: Output Eviews 9.0

a. Based on the table above, it can be seen that the calculated F value is 23.79983 with a significance level of 0.00000 . While the F table is 5.65. By using $\alpha$ level $(0.05)$ or $5 \%$, then $\mathrm{Ha}$ is accepted where $0.00000<0.05$. Ha acceptance is evidenced by the calculation that the value of Fcount $>$ Ftable (0.05) $(23.79983>5.65)$, so it can be concluded that Free Cash Flow, Financial Distress and Debt Policy have significant effect on Earnings Management.

b. Based on the table, the partial test results regarding the influence of the Free Cash Flow variable on Earnings Management show statistical value tcount of 5.982910. The value of 
ttable at the significant level $\alpha=0.05$ and degrees of freedom $\mathrm{df}=(\mathrm{nk}-1)=215-3-1=211$ obtained ttable of 1.960 . When compared to the value of tcount with the value of ttable, then tcount $>$ ttable $(5.982910>1.960)$ with a probability value of $0.0000<0.05$, this means that $\mathrm{HO}$ is rejected and $\mathrm{Ha}$ is accepted. This concludes that Free Cash Flow partially has a significant positive effect on Earnings Management.

c. The results of testing the effect of the Financial Distress variable on Earnings Management show statistical value tcount of 3.691201. The value of ttable at the significant level $\alpha=0.05$ and degrees of freedom $\mathrm{df}=(\mathrm{nk}-1)=215-3-1=211$ obtained ttable of 1.960. When compared to the value of tcount with the value of ttable, then tcount $>$ ttable $(3.691201>1.960)$ with a probability value of $0.0002<0.05$, this means that $\mathrm{H} 0$ is rejected and $\mathrm{Ha}$ is accepted, this concludes that partially financial distress has a significant positive effect on Earnings Management.

d. The results of testing the effect of the Debt Policy variable on Earnings Management show statistical value tcount of -2.719016 . The value of ttable at the significant level $\alpha=$ 0.05 and degrees of freedom $\mathrm{df}=(\mathrm{nk}-1)=215-3-1=211$ obtained ttable of $-1,960$. When compared to the value of tcount with the value of ttable then -tcount <-ttable $(-2.719016$ $<-1.960$ ) with a probability value of $0.0012<0.05$ means that $\mathrm{H} 0$ is accepted and $\mathrm{Ha}$ is rejected, this means that partially Debt Policy has a significant negative effect on Earnings Management.

The above research results indicate that free cash flow has a positive effect on earnings management. This shows that the higher the level of free cash flow, the potential for earnings management practices to occur in the company. Companies that have high cash flows have considerable flexibility to invest, in line with agency theory where this will have an impact on the possibility of a conflict of interest between the principal and the agent who each has an interest. Large cash flows must then be managed properly and wisely on the right type of investment; this conflict of interest can lead to failure in choosing the right investment. This condition must be saved by management in the interest of showing their best image which creates opportunities for earnings management to be carried out in the company. This is in line with the results of research from [18] and [19] which state that free cash flow has a positive effect on earnings management. Whereas in contrary, [20], as well as [3] suggest that free cash flow has a negative effect on earnings management.

The second result states that financial distress has a positive effect on earnings management. This means that the higher the level of financial distress will have an impact on more opportunities for companies to carry out earnings management. Financial distress shows that the company is unable to manage and maintain the financial stability of the company, in banking companies, this failure can be caused by a decrease in the number of customers using bank facilities both in funding and lending activities. A decrease in the number of products used by customers will have an impact on bank operational losses and current year losses. This loss will have an impact on the decline in company performance that leads to bankruptcy. Bankruptcy conditions will make stakeholders panic and withdraw their investment or make potential investors fail to invest their funds, which then raises opportunities for management to take profit manipulation actions (earnings management).

This is in line with the research results of [21] and [11] which state that financial distress has a positive effect on earnings management. While the research results of [3] show that financial distress has a negative effect on earnings management. The results of research relating to debt policy show that debt policy has a negative effect on earnings management. This means that the higher the DER level (debt to equity ratio), the higher the company's 
capital originating from debt, the smaller the chance of earnings management in the company. In line with the hypothesis of debt contracts in positive accounting theory which was later clarified by [22], states that the higher the level of corporate debt, the closer the company is to the risks associated with debt covenants, and the higher the probability of violating the debt covenant. Therefore, management tends not to try to take actions that will increase income. This is in line with the results of research from [23], which state that debt policy represented by a debt to equity ratio has a significant negative effect on earnings management. However, it contradicts [15] which states that debt policy management affects positively and insignificantly on earnings management, and [24] which state that debt policy represented by a debt to equity ratio has a positive and significant effect on earnings management.

\section{Conclusion}

The findings conclude that high free cash flow opens opportunities for company management to carry out earnings management. The management of the company has an interest in getting high bonuses and incentives. Companies experiencing financial distress will tend to carry out earnings management. This is to cover the condition of companies experiencing financial difficulties to stakeholders by manipulating financial reports. The debt policy adopted by the company is in accordance with the company policy. Even though the debt to asset ratio is high, the company's management in carrying out earnings management is relatively low. The limitation in this research is that the research object is only in the scope of the banking sector. Therefore, we suggest for further researchers to add a wider research object area and put more variables which were not examined in this study.

\section{References}

[1] R. L. Watts and J. L. Zimmerman, "Positive Accounting Theory: A Ten Year Perspective," Account. Rev., vol. 65, no. 1, pp. 131-156, 1990.

[2] H. S. Sulistyanto, Manajemen Laba, Teori dan Model Empiris. Jakarta: Grasindo, 2008.

[3] A. W. Ghazali, N. A. Shafie, and Z. M. Sanusi, "Earnings Management: An Analysis of Opportunistic Behaviour, Monitoring Mechanism and Financial Distress," Procedia Econ. Financ., vol. 28, no. April, pp. 190-201, 2015, doi: 10.1016/s2212-5671(15)01100-4.

[4] R. B. Bukit and T. M. Iskandar, "Surplus free cash flow, earnings management and audit committee,” Int. J. Econ. Manag., vol. 3, no. 1, pp. 204-233, 2009.

[5] M. C. Jensen and W. H. Meckling, "Theory Of Them Firm: Managerial Behavior, Agency Costs and Ownership Structure," J. financ. econ., vol. 3, pp. 305-360, 1976.

[6] Kodriyah and A. Fitri, "Pengaruh Free Cash Flow dan Leverage terhadap Manajemen Laba Pada Perusahaan Manufaktur di BEI,”J. Akunt., vol. 3, no. 2, 2017.

[7] Widarjo \& Setiawan, "Pengaruh Rasio Keuangan Terhadap Kondisi Financial Distress Perusahaan Otomotif," J. Bisnis dan Akunt., vol. 11, no. 2, pp. 107-119, 2009, [Online]. Available: http://jurnaltsm.id/index.php/JBA/article/view/174.

[8] S. B. M. Zeni and R. Ameer, "Turnaround prediction of distressed companies: evidence from Malaysia," J. Financ. Report. Account., vol. 8, no. 2, pp. 143-159, 2010, doi: $10.1108 / 19852511011088398$

[9] T. C. Opler and S. Titman, "Financial Distress and Corporate Performance," J. Finance, vol. 49, no. 3, pp. 1015-1040, 1994. 
[10] B. Jaggi and P. Lee, "Earnings Management Response to Debt Covenant Violations and Debt Restructuring," J. Accounting, Audit. Financ., vol. 17, no. 4, 2002.

[11] A. T. Gupta and I. W. Suartana, "Pengaruh Financial Distress dan Kualitas Corporate Governance pada Manajemen Laba," E-Jurnal Akunt. Univ. Udayanan, vol. 23, no. 2, pp. 1495-1520, 2018.

[12] E. Setiana and R. Sibagariang, "Pengaruh Free Cash Flow dan Kepemilikan Manajerial terhadap Kebijakan Hutang Pada perusahaan Manufaktur yang Terdaftar di Bursa Efek Indonesia," Telaah Akunt., vol. 15, 2013.

[13] V. J. Horne and J. M. Wachowicz, Prinsip-Prinsip Manajemen Keuangan (Fundamental of Financial Management). Edisi 12. Jakarta: Salemba Empat, 2005.

[14] M. P. Tampubolon, Manajemen Keuangan, Edisi Pertama. Jakarta: Ghalia Indonesia, 2005.

[15] D. Purnama, "Pengaruh Profitabilitas, Leverage, Ukuran Perusahaan, Kepemilikan Institusional dan Kepemilikan Manajerial terhadap Manajemen Laba," JRKA, vol. 3, no. 1, pp. 1-14, 2017.

[16] T. Widyastuti, "Pengaruh Struktur Kepemilikan dan Kinerja Keuangan terhadap Manajemen Laba: Studi Pada Perusahaan Manufaktur Di BEI." pp. 30-41, 2009, [Online]. Available: http://eprints.undip.ac.id/35153/.

[17] I. M. A. Partayadnya and I. M. S. Suardikha, "Pengaruh Mekanisme GCG, Kualitas Audit, dan Leverage terhadap Manajemen Laba pada Perusahaan Manufaktur di BEI,” E-Jurnal Akunt. Univ. Udayana, vol. 25, no. 1, pp. 31-53, 2018.

[18] C. S. F. Hastuti, "Pengaruh Arus Kas Bebas, Arus Kas Operasi, Kepemilikan Manajerial, Leverage Keuangan Dan Ukuran Perusahaan Terhadap Manajemen Laba Pada Perusahaan Manufaktur Yang Terdaftar Di Bursa Efek Indonesia,” J. AKBIS Media Ris. Akunt. dan Bisnis, vol. 3, no. 1, pp. 1126, 2019.

[19] V. A. Tandean, "Pengaruh Arus Kas Bebas dan Tingkat Hutang terhadap Manajemen Laba," J. Akunt. Perpajak., vol. 1, no. 1, pp. 1689-1699, 2019.

[20] A. R. Sari and W. Meiranto, "Pengaruh Perilaku Opportunistik, Mekanisme Pengawasan, Dan Financial Distress Terhadap Manajemen Laba,” Diponegoro J. Account., vol. 6, no. 4, pp. 67-83, 2017.

[21] W. Chairunesia, P. R. Sutra, and S. M. Wahyudi, "Pengaruh Good Corporate Governance dan Financial Distress terhadap Manajemen Laba pada Perusahaan Indonesia yang Masuk Dalam Asean Corporate Governance Scorecard," Profita Komun. Ilm. Akunt. dan Perpajak., vol. 11, no. 2, pp. 232-250, 2018.

[22] A. R. Belkaoui, Accounting Theory, Edisi Lima. Jakarta: Salemba Empat, 2007.

[23] P. T. Arthawan and I. W. P. Wirasedana, "Pengaruh Kepemilikan Manajerial, Kebijakan Utang, dan Ukuran Perusahaan terhadap Manajemen Laba," E-Jurnal Akunt. Univ. Udayana, vol. 22, no. 1, pp. $1-29,2018$.

[24] N. F. Kusumawardani and R. R. Dewi, "Motivasi Bonus, Pajak, Dan Utang Dalam Tindakan Manajemen Laba (Studi Perusahaan Manufaktur Yang Terdaftar Di Bursa Efek Indonesia Periode 2013-2015)," Media Ris. Akuntansi, Audit. dan Inf., vol. 16, no. 1, p. 79, 2017, doi: 10.25105/mraai.v16i1.2072. 